\title{
PENATAAN DAN PENGELOLAAN WILAYAH KELAUTAN PERSPEKTIF OTONOMI DAERAH DAN PEMBANGUNAN BERKELANJUTAN
}

\author{
Basri \\ Fakultas Hukum Universitas Borneo Tarakan \\ e-mail: basriubt@gmail.com
}

\begin{abstract}
ABSTRAK
Penataan wilayah kelautan diperlukan dalam kaitannya pengaturan pemanfaatan laut secara optimal dengan mengakomodasi semua kepentingan sekaligus sebagai upaya menghindari adanya konflik pemanfaatan ruang di laut dan pemanfaatan sumber daya kelautan sehingga harus diberikan batas yang jelas antara zona pemanfaatan yang satu dengan zona yang lain, sehingga wilayah laut dapat memberikan manfaat bagi segenap masyarakat di Indonesia khususnya masyarakat pesisir. Tujuan dari penulisan ini adalah untuk mengkaji tentang penataan dan pengelolaan wilayah dan sumber daya kelautan secara terpadu dalam Hukum Agraria Perspektif Otonomi Daerah, serta untuk menganalisis penataan dan pengelolaan sumber daya kelautan secara berkelanjutan dalam Hukum Agraria Perspektif Otonomi Daerah. Pengelolaan kawasan pesisir dan lautan hendaknya dilakukan secara terpadu, meliputi kawasan daratan dan kawasan lautan, mencakup berbagai sektor dan subsektor yang berbeda, pembangunan berkelanjutan adalah pembangunan yang diorientasikan untuk memenuhi kebutuhan generasi sekarang tanpa mengorbankan kemampuan generasi yang akan datang.
\end{abstract}

Kata Kunci: pengelolaan, kelautan, otonomi daerah dan berkelanjutan.

\begin{abstract}
Structuring the sea area required in relation to setting the optimal utilization of the sea to accommodate all interests as well as efforts to avoid any conflict in the sea of space utilization and utilization of marine resources and should be given a clear boundary between the zones use zone one with another, so that the sea area can provide benefits for all the people in Indonesia, especially coastal communities. Integrated coastal zone management and sustainability into account. The purpose of this paper is to study about the structuring and management of marine areas and resources in an integrated manner in Agrarian Perspective of Regional Autonomy Law, as well as to analyze the structuring and management of marine resources in a sustainable manner in the Regional Autonomy Law of Agrarian Perspective. Coastal and ocean management should be done in an integrated manner, covering lands and seas region, spanning multiple sectors and sub-sectors are different, sustainable development is development oriented to meet the needs of the present without compromising the ability of future generations.
\end{abstract}

Keywords: management, marine, local autonomy and sustainable.

\section{PENDAHULUAN}

Wilayah laut Indonesia memiliki potensi kelautan dan sumber daya alam yang sangat besar dan beragam, baik yang dapat diperbaharui maupun tidak dapat diperbaharui berupa potensi wilayah kelautan, sumber daya alam, dan jasa kelautan. Sumber daya yang dapat diperbaharui misalnya sumber daya perikanan tangkap dan budidaya, potensi biota nonikan serta sumbersumber energi nonkonvensional, sedangkan sumber daya yang tidak dapat diperbaharui baik misalnya potensi minyak dan gas bumi maupun potensi mineral serta harta karun (Rokhmin Dahuri, 2001:2). Sumber daya kelautan sangat rentan terhadap faktor eksternal berupa tekanan eksploitasi yang berlebihan, sangat rentan terhadap aktifitas manusia yang merusak, seperti destructif fishing, penambangan terhadap karang dan pasir, ternyata sangat rawan terhadap bahaya pencemaran terhadap laut, seperti tumpahan minyak dari kapal, buangan limbah kimia berbahaya yang mengandung banyak logam-logam berat dari berbagai aktifitas manusia di daratan, karena dapat 
memberikan dampak besar terhadap menurunnya kualitas. Wilayah laut serta sumber daya kelautan juga rentan konflik pemanfaatan ruang antar berbagai stakeholder terkait, oleh sebab itu kelautan merupakan multi sektor serta lintas departemen, juga terdapat kepentingan pemerintah pusat dan pemerintah daerah, tanpa perencanaan pengelolaan yang baik dalam pemanfaatan sumber dayanya akan dapat berdampak pada konflik pemanfaatan ruang di laut.

Penataan terhadap wilayah kelautan diperlukan dalam kaitannya pengaturan pemanfaatan laut secara optimal dengan mengakomodasi semua kepentingan sekaligus sebagai suatu upaya menghindari adanya konflik pemanfaatan ruang di laut dan pemanfaatan sumberdaya kelautan sehingga harus diberikan batas yang jelas antara zona pemanfaatan yang satu dengan zona yang lain.

Batas pemanfaatan wilayah laut belum secara keseluruhan memiliki kepastian hukum sebagian besar dikarenakan tumpang tindihnya peraturan yang sudah ada sehingga diperlukan pengaturan pengelolaan yang dapat mengelola wilayah laut dengan optimal, sehingga wilayah laut dapat memberikan manfaat bagi segenap masyarakat di Indonesia khususnya masyarakat pesisir.

Salah satu penyebab dari belum dapat terkelolanya potensi wilayah laut secara optimal adalah karena sistem kelembagaan, yaitu kelembagaan yang ada belum mendukung sektor kelautan dan kurangnya keterpaduan dalam hal perencanaan pengelolaan sumberdaya laut dan pesisir, selain itu juga pola pemanfaatannya yang cenderung bersifat merusak dan mengabaikan generasi berikutnya, hendaknya sumberdaya kelautan diarahkan untuk keterpaduan dalam perencanaan pengelolaan dan keseimbangan antara kepentingan yang ada tanpa mengabaikan generasi mendatang. Perencanaan dalam pengelolaan sumber daya kelautan sangat terkait dengan konsep penataan terhadap ruang dan wilayah.

Kebijakan penataan ruang laut pada umumnya, dan dalam pengelolaan sumberdaya pesisir lautan dewasa ini masih bersifat parsial, baik ditinjau dari sisi cara pandang sektoralisme parsial atau sektor kegiatan maupun sektor wilayah atau keruangan, pembangunan daratan terpisah dengan pembangunan kelautan (Kusumastanto Tridoyo, 2003:66), maupun dari sudut pandang pengutamaan strategi tertentu (Victor P.H. Nikijuluw, 2002:2). Selama ini teori dan paradigma pembangunan mengasumsikan bahwa articulation space dalam uraian di atas seluruh rencana dan pelaksanaan pembangunan digelar, adalah dunia daratan bukan dunia lautan (Apridar, 2010:80).
Secara eksplisit Undang-Undang Nomor 26 Tahun 2007 tentang Penataan Ruang, LNRI-2007-68, TLN4725 (yang selanjutnya disebut UUTR) ternyata tidak mengatur secara tegas dan secara jelas mengenai tata ruang laut. Pasal 6 ayat (5) UUTR menyatakan ruang laut dan ruang udara, pengelolaannya diatur dengan undang-undang tersendiri. Dari perspektif kewilayahan dengan diaturnya pengelolaan ruang laut secara tersendiri, maka akan berdampak terhadap wewenang pengelolaan sumber daya di wilayah laut maupun pemanfaatan ruang di wilayah laut baik oleh Pemerintah Pusat maupun oleh Pemerintah Daerah (Propinsi dan Kabupaten/Kota).

Kurangnya pengaturan mengenai konsep-konsep pengelolaan wilayah laut, tidak terlepas dari karakter dan pola pembangunan yang cenderung berorientasi hanya pada daratan (land based oriented) sehingga pembangunan-pembangunan yang berorientasi pada wilayah laut dirasakan cukup asing dan tertinggal. Demikian pula desentralisasi kelautan dalam era otonomi daerah masih menimbulkan banyak persoalan mengenai pengelolaan sumber daya kelautan serta batas-batas pengelolaan dan pemanfaatan ruang di wilayah laut sehingga dapat menimbulkan berbagai konflik dan tumpang tindih antar kewenangan dalam pelaksanaannya.

Dari latar belakang dan uraian tersebut di atas penulis tertarik untuk membuat tulisan yang berjudul Penataan dan Pengelolaan Wilayah Kelautan dalam Hukum Agraria Perspektif Otonomi Daerah. Maka rumusan permasalahannya sebagai berikut, yaitu pengelolaan wilayah kelautan dan pesisir terpadu dalam perspektif otonomi daerah, dan pengelolaan wilayah kelautan berkelanjutan dalam perspektif otonomi daerah.

\section{PEMBAHASAN}

\section{Hukum Agraria sebagai Hukum yang Mengatur Bumi, Air, Ruang Angkasa, dan Kekayaan Alam yang Terkandung Didalamnya}

Hukum Agraria tidak mengenai urusan tanah saja, di dalam Pasal 1 ayat (4) dan (5) Undang-Undang Nomor 5 Tahun 1960 tentang Peraturan Dasar PokokPokok Agraria, LNRI-1960-104, TLN-2043 (yang selanjutnya disebut UUPA), memberikan pengertian bahwa dalam pengertian bumi, selain permukaan bumi, termasuk pula tubuh bumi dibawahnya serta yang berada di bawah air, dan dalam pengertian air termasuk baik perairan di pedalaman maupun laut wilayah Indonesia. A.P. Parlindungan menyatakan bahwa pengertian agraria mempunyai ruang lingkup, yaitu dalam arti sempit bisa berwujud hak atas tanah, 
atau pun pertanian saja, sedangkan Pasal 1 dan 2 UUPA dalam pengertian yang meluas yaitu bumi, air, ruang angkasa dan kekayaan alam yang terkandung didalamnya (A.P. Parlindungan, 1998:5).

Salah satu konsep dasar pemikiran tata ruang menurut UUPA, dapat kita temukan dalam Pasal 2, 14, dan 15. Sesuai dengan Pasal 33 ayat (3) UndangUndang Dasar 1945 (yang selanjutnya disebut UUD 1945) tentang pengertian hak menguasai dari negara terhadap konsep tata ruang, Pasal 2 UUPA memuat wewenang untuk mengatur dan menyelenggarakan peruntukan penggunaan, persediaan dan pemeliharaan bumi, air dan ruang angkasa; dengan menentukan dan mengatur hubungan hukum antara orang-orang dengan bumi, air dan ruang angkasa; menentukan dan mengatur hubungan hukum antara orang dan perbuatan-perbuatan hukum yang mengenai bumi, air, dan ruang angkasa (M. Daud Silalahi, 2001:79).

Konsep tata ruang dalam tiga dimensi tersebut di atas sangat terkait dengan mekanisme kelembagaan dan untuk perencanaannya tersebut diatur dalam Pasal 14 UUPA menyatakan bahwa pemerintah dalam rangka membuat suatu rencana umum mengenai persediaan, peruntukan, dan penggunaan bumi, air, dan ruang angkasa; dan berdasarkan rencana umum tersebut Pemda mengatur persediaan, peruntukan dan penggunaan bumi, air, dan ruang angkasa.

Pasal 15 UUPA mengatur pemeliharaan tanah, termasuk menambah kesuburannya serta mencegah kerusakannya merupakan kewajiban setiap orang, badan hukum, instansi yang mempunyai hubungan hukum dengan tanah itu dengan memperhatikan pihak ekonomi lemah. Ketentuan tersebut memberikan hak penguasan kepada negara atas seluruh sumber daya alam Indonesia, dan memberikan kewajiban kepada negara untuk menggunakan sebesar-besarnya bagi kemakmuran rakyat. Hal tersebut itu mengandung makna, bahwa negara mempunyai kewenangan untuk melakukan pengelolaan-pengelolaan, mengambil dan memanfaatkan sumber daya alam guna terlaksananya kesejahteraan rakyat yang dikehendaki.

\section{Penataan Ruang sebagai Sarana Penataan dan Pengelolaan Sumber Daya Alam}

Menurut Pasal 1 angka 1 UUTR, yang dimaksud dengan ruang adalah wadah yang meliputi ruang darat, ruang laut, dan ruang udara, dan juga termasuk ruang di dalam bumi sebagai satu kesatuan wilayah, merupakan suatu tempat untuk manusia dan makhluk lain hidup, melakukan kegiatan, dan memelihara kelangsungan hidupnya. Dalam Surat Keputusan Menteri Pemukiman dan Prasarana Wilayah Nomor
327/KPTS/2002 tentang Penetapan Enam Pedoman Bidang Penataan Ruang, memberikan pengertian tentang ruang ialah wadah yang meliputi ruang daratan, ruang lautan, ruang udara sebagai satu kesatuan wilayah tempat manusia dan makhluk hidup lainnya dan melakukan kegiatan serta memelihara kelangsungan hidupnya.

Pasal 1 angka 5 UUTR menyebutkan pengertian tentang penataan ruang ialah suatu sistem proses terhadap perencanaan tata ruang, dan pemanfaatan ruang dan pengendalian pemanfaatan ruang. Tata ruang berarti susunan ruang yang teratur. Dalam kata teratur tercakup pengertian serasi dan sederhana sehingga mudah dipahami dan dilaksanakan, karena itu pada tata ruang, yang ditata adalah tempat berbagai kegiatan serta sarana dan prasarananya .

Suatu tata ruang yang baik dapat dihasilkan dari kegiatan menata ruang yang baik disebut penataan ruang. Dalam pengertian ini penataan ruang terdiri dari tiga kegiatan utama yaitu tentang perencanaan tata ruang, perwujudan tata ruang, dan pengendalian tata ruang (M. Daud Silalahi, 2001:80). Perencanaan tata ruang merupakan kegiatan merumuskan dan menetapkan pemanfaatan ruang dan kaitannya atau hubungan antara berbagai manfaat ruang, berdasarkan kegiatan-kegiatan yang perlu dan dapat dilaksanakan untuk memenuhi kebutuhan manusia di masa yang akan datang. Tingkat manfaat ruang ini juga akan bergantung pada pemanfaatan sumber daya alam yang tersedia atau yang dapat disediakan secara optimal. Dengan demikian perencanaan suatu tata ruang akan menghasilkan rencana tata ruang untuk memberikan gambaran tentang ruang mana, untuk kegiatan apa dan kapan (M. Daud Silalahi, 2001:81).

Tujuan dari perencanaan tata ruang adalah untuk menyerasikan antara lahan dan ruang dapat dilakukan secara optimal, efisien, dan serasi. Sedangkan tujuan diadakannya perencanaan tata ruang adalah untuk mengarahkan sturuktur dan lokasi beserta hubungan fungsionalnya yang harus serasi dan seimbang dalam rangka pemanfaatan sumber daya manusia, sehingga tercapainya hasil pembangunan yang optimal dan efisien bagi peningkatan kualitas manusia dan kualitas lingkungan hidup secara berkelanjutan.

Penataan ruang sebagai suatu proses perencanaan tata ruang, pemanfaatan ruang, dan pengendalian pemanfaatan ruang merupakan suatu kesatuan sistem yang tidak dapat terpisahkan satu sama lainnya. Untuk menciptakan suatu penataan ruang yang serasi harus memerlukan suatu peraturan perundang-undangan yang serasi pula di antara peraturan pada tingkat tinggi sampai pada peraturan pada tingkat bawah, 
sehingga terjadinya suatu koordinasi dalam penataan ruang.

Dalam pejelasan umum Nomor 4 dari UUTR menyebutkan, bahwa ruang sebagai sumber daya pada dasarnya tidak mengenal batas wilayah. Namun untuk mewujudkan ruang wilayah nasional yang aman dan nyaman, produktif, dan berkelanjutan berlandaskan Wawasan Nusantara dan Ketahanan Nasional, serta sejalan dengan kebijakan otonomi daerah yang nyata, luas, dan bertanggungjawab, penataan ruang menuntut kejelasan pendekatan proses perencanaanya demi menjaga keselarasan, keserasian, keseimbangan, dan keterpaduan antar daerah, antar pusat dan daerah, antar sektor dan antar pemangku kepentingan. Dalam UUTR, penataan ruang didasarkan pada pendekatan sistem, fungsi utama kawasan, wilayah administratif, kegiatan kawasan, dan nilai strategis kawasan.

Menurut pendapat Herman Hermit, asas hukum yang paling utama yaitu asas keadilan, maka dalam hal ini arah dan kerangka pemikiran serta pendekatanpendekatan dalam pengaturan (substansi peraturan perundang-undangan), yaitu termasuk juga UUTR, wajib dijiwai asas keadilan (Herman Hermit, 2008: 68 ). Asas penataan ruang menurut UUTR adalah di dalam kerangka Negara Kesatuan Republik Indonesia (NKRI), penataan ruang diselenggarakan berdasarkan atas asas-asas: keterpaduan; keserasian, keselarasan, keseimbangan; keberlanjutan; dan keberdayagunaan keberhasilgunaan; keterbukaan; dan kebersamaan kemitraan; perlindungan dan kepentingan umum; kepastian hukum, keadilan; dan akuntabilitas (Pasal 2 UUTR).

Kesembilan asas penyelenggaraan penataan ruang tersebut pada intinya merupakan norma-norma yang diambil untuk bisa memayungi semua kaidah-kaidah pengaturan penataan ruang.

Penyelenggaraan penataan ruang bertujuan untuk mewujudkan ruang wilayah nasional yang aman, nyaman, produktif, dan berkelanjutan berlandaskan Wawasan Nusantara dan Ketahanan Nasional dengan terwujudnya keharmonisan antara lingkungan alam dan lingkungan buatan; terwujudnya keterpaduan dalam penggunaan sumber daya alam dan sumber daya buatan dengan memperhatikan sumber daya manusia; dan terwujudnya pelindungan fungsi ruang dan pencegahan dampak negatif terhadap lingkungan akibat pemanfaatan ruang.

Menurut Hermit klasifikasi penataan ruang bukan merupakan hal baru dalam pengaturan sistem penataan ruang kita. Menurut UUTR klasifikasi penataan ruang tertuang pada Pasal 4 menyatakan bahwa penataan ruang diklasifikasikan berdasarkan sistem, fungsi utama kawasan, dan wilayah administratif, kegiatan kawasan, dan nilai strategis kawasan.

Klasifikasi dalam penataan ruang baik berdasarkan sistem, fungsi utama kawasan-kawasan, wilayah administratif, kegiatan kawasan, dan nilai strategi kawasan tertuang pada Pasal 5 dan Pasal 6 UUTR.

Pada Pasal 5 UUTR mengatakan bahwa dalam ayat: 1 . Penataan ruang berdasarkan sistem terdiri atas sistem wilayah dan sistem internal perkotaan; 2 . Penataan ruang berdasarkan fungsi utama kawasan terdiri atas kawasan lindung dan kawasan budi daya; 3. Penataan ruang berdasarkan wilayah administratif terdiri atas penataan ruang wilayah nasional, penataan ruang wilayah propinsi, dan penataan ruang wilayah Kabupaten atau Kota; 4. Penataan ruang berdasarkan kegiatan kawasan terdiri atas penataan ruang kawasan perkotaan dan penataan ruang kawasan pedesaan; 5 . Penataan ruang berdasarkan nilai strategis kawasan terdiri atas penataan ruang kawasan strategis nasional, penataan ruang kawasan strategis Propinsi, penataan ruang kawasan strategis Kabupaten/Kota (Herman Hermit, 2008:68).

Dalam Pasal 6 UUTR menyatakan bahwa dalam ayat: 1 . Penataan ruang dapat diselenggarakan dengan memperhatikan: a. kondisi fisik di wilayah Negara Kesatuan Republik Indonesia yang rentan terhadap bencana; $b$. potensi sumber daya alam, sumber daya manusia, dan sumber daya buatan; kondisi ekonomi, sosial, budaya, politik, hukum, pertahanan keamanan, dan lingkungan hidup, serta ilmu pengetahuan dan teknologi sebagai satu kesatuan; dan c. geostrategi, geopolitik, geoekonomi; 2. Penataan ruang wilayah nasional, penataan ruang wilayah Propinsi, penataan ruang wilayah Kabupaten/Kota dilakukan secara berjenjang dan komplementer; 3. Penataan ruang wilayah nasional meliputi ruang wilayah yurisdiksi dan wilayah kedaulatan nasional mencakup ruang darat, ruang laut, dan ruang udara, termasuk ruang di dalam bumi sebagai satu kesatuan; 4. Penataan ruang wilayah propinsi dan kabupaten/kota meliputi ruang darat, ruang laut, dan ruang udara, termasuk ruang di dalam bumi sesuai dengan ketentuan peraturan perundangundangan; 5. Ruang laut dan ruang udara, pengelolaannya akan diatur dengan undang-undang tersendiri.

\section{Otonomi Daerah dan Pembagian Kewenangan dalam Penataan dan Pengelolaan Sumber Daya Alam}

Otonomi daerah yang merupakan suatu keluasan dalam bentuk hak dan kewenangan serta kewajiban dan tanggung jawab badan pemerintah daerah untuk 
mengatur dan mengurus rumah tangganya sesuai keadaan dan kemampuan daerahnya sebagai wujud manifestasi dari desentralisasi atau devolusi (Martin Jimung, 2005:38). Sesuai Undang-Undang Nomor 32 Tahun 2004 tentang Pemerintahan Daerah (LNRI2004-125, TLN-4437) (yang selanjutnya disebut UU Pemda), yang menyelenggarakan definisi otonomi daerah ialah hak, wewenang, dan kewajiban daerah otonom untuk mengatur dan mengurus sendiri urusan pemerintahan dan kepentingan masyarakat setempat sesuai dengan peraturan perundang-undangan.

Selanjutnya UU Pemda mendefinisikan Daerah Otonom (yang selanjutnya disebut daerah) adalah suatu kesatuan masyarakat hukum yang mempunyai batas-batas wilayah yang berwenang mengatur dan mengurus urusan pemerintahan dan kepentingan masyarakat setempat menurut prakarsanya sendiri berdasarkan aspirasi masyarakat dalam sistem Negara Kesatuan Republik Indonesia.

Menurut pendapat Eko Sabar Prihatin di dalam hal pengelolaan sumber daya alam, otonomi daerah mempunyai arti yaitu sebagai berikut: Menyesuaikan kebijakan pengelolaan sumber daya alam dengan ekosistem setempat; dengan menghormati kearifan tradisional yang sudah dikembangkan masyarakat dalam hal pengelolaan-pengelolaan sumber daya alam dan lingkungan hidup yang secara lestari; Tidak berdasarkan pada batas-batas administratif, tetapi dengan berdasarkan batas ekologi (bioecoregion); Meningkatkan kemampuan daya dukung lingkungan setempat dan bukan menghancurkan daya dukung ekosistem dengan eksploitasi yang melewati daya dukung; Pelibatan secara aktif pada masyarakat adat dan penduduk setempat sebagai pihak yang paling berkepentingan (menentukan) dalam hal pembuatan kebijakan pengelolaan-pengelolaan sumber daya alam dan lingkungan hidup (Eko Sabar Prihatin, 2006:17).

\section{Pengelolaan Wilayah Kelautan Terpadu dalam Perspektif Otonomi Daerah}

Untuk melihat pembangunan dan pengelolaan secara terpadu wilayah laut tak dapat dilepaskan dari wilayah pesisir serta konsep ekosistem yang terkait dengan wilayah daratan, lautan serta pesisir. Ada banyak pengertian mengenai wilayah pesisir. Secara umum terdapat kesepakatan bahwa wilayah pesisir adalah suatu wilayah peralihan antara daratan dan laut (Rohmin Dahuri, 2001:6).

Di Indonesia pengertian yang digunakan untuk wilayah pesisir sebagai wilayah yang merupakan kawasan pertemuan antara daratan dan lautan, ke arah darat meliputi bagian daratan baik kering maupun terendam air yang masih dipengaruhi oleh prosesproses yang berkaitan dengan laut atau sifat-sifat laut seperti pasang surut, angin laut dan perembesan air asin. Sedangkan ke arah laut kawasan pesisir mencakup bagian laut yang masih dipengaruhi oleh proses alami yang terjadi di darat seperti sedimentasi dan aliran air tawar, maupun yang disebabkan kegiatan manusia di darat seperti penggundulan hutan dan pencemaran (Rohmin Dahuri, 2001:8).

Secara ekologis, batas ke arah laut dari suatu wilayah pesisir yaitu mencakup daerah perairan laut yang masih dipengaruhi oleh proses-proses alamiah (seperti aliran air tawar dari sungai maupun run-off) maupun kegiatan manusia (seperti pencemaran dan sedimentasi) yang terjadi di daratan. Sementara itu, batas ke arah darat adalah mencakup daerah daratan yang masih dapat dipengaruhi oleh proses-proses laut, seperti jangkauan pengaruh pasang surut, salinitas air laut, dan angin laut. Oleh karena itu, batas ke arah darat dan ke arah lautan dari suatu wilayah pesisir bersifat sangat site specific atau bergantung pada kondisi biogeofisik wilayah berupa topografi dan geomorfologi pesisir, dan keadaan pasang surut dan gelombang, dengan kondisi Daerah Aliran Sungai (DAS) (Bengen, 2005:95). Menurut kesepakatan internasional bahwa wilayah pesisir didefinisikan sebagai wilayah peralihan antara laut dan daratan, ke arah darat mencakup daerah yang masih terkena pengaruh percikan air laut atau pasang surut, dan ke arah laut meliputi daerah paparan benua (continental shelf) (Press Washington D.C., 1994:9).

Konsep pengelolaan di wilayah pesisir terpadu, pengelolaan kawasan pesisir dan lautan dilakukan secara terpadu, meliputi kawasan daratan dan kawasan lautan, mencakup berbagai sektor dan subsektor yang berbeda, menyangkut interaksi pemanfaatan sumber daya alam dan sumber daya buatan serta kegiatan dan perilaku sumber daya manusia, yang mempunyai berbagai aspek yaitu: fisik, biologi, kimia, ekonomisosial, kelembagaan dan lain-lainnya, dan seringkali menyangkut kepentingan dari wilayah administrasi yang berbeda. Menurut Rokmin Dahuri pengelolaan wilayah pesisir secara terpadu adalah merupakan suatu pendekatan pengelolaan wilayah pesisir yang melibatkan dua atau lebih ekosistem, sumber daya, dan kegiatan pemanfaatan (pembangunan) secara terpadu (integrated) guna mencapai pembangunan wilayah pesisir secara berkelanjutan. Keterpaduan sendiri mengandung 3 (tiga) dimensi yaitu sektoral, bidang ilmu, keterkaitan ekologis (Rohmin Dahuri, 2001:12). 
Keterpaduan secara sektoral berarti bahwa perlu ada koordinasi tugas, wewenang dan tanggung jawab antar sektor atau instansi pemerintah pada tingkat pemerintahan tertentu (horizontal integration) dan antar tingkat pemerintahan dari mulai tingkat Desa, Kecamatan, Kabupaten, Propinsi, sampai tingkat pusat (vertical integration). Keterpaduan dari sudut pandang keilmuan mensyaratkan bahwa di dalam pengelolaan wilayah pesisir hendaknya dapat dilaksanakan atas dasar pendekatan interdisiplin ilmu (interdisciplinary approaches) yang melibatkan bidang ilmu ekologi, ekonomi, teknik, sosiologi, hukum dan lainnya yang relevan. Keterpaduan dilihat dari keterkaitan ekologis karena wilayah pesisir merupakan pertemuan yang saling mempengaruhi dari hulu sampai hilir, antara wilayah daratan dan wilayah perairan.

Dalam hal melakukan pengelolaan Sumber Daya Kelautan harus dengan mengutamakan 3 (tiga) prinsip keterpaduan antara lain sebagai berikut; Prinsip ke1, yaitu keterpaduan antar ekosistem darat dan laut, dimana harus mempertimbangkan berbagai dampak biofisik dan sosial-ekonomi yaitu yang terkait antara ekosistem darat dan lautan, karena merupakan satu kesatuan ekologi yang tidak bisa dilepas pisahkan. Artinya ancaman dan kerusakan terhadap ekosistem daratan akan berimplikasi negatif terhadap ekosistem lautan, begitu pula sebalinya.

Prinsip ke-2, yaitu keterpaduan antar sektor dan atau stakeholder, karena berbagi sektor yang terkait dengan pengelolaan perairan pesisir tidak bisa berjalan sendiri-sendiri dalam melakukan aktifitasnya, apalagi perairan pesisir merupakan pusat pemanfaatan dan kegiatan berbagai sektor yang berhubungan dengan daratan maupun lautan, seperti jasa transportasi laut, industri galangan kapal, perikanan, pertambangan, kepariwisataan, kehutanan, pertanian, dan industri manufaktur di daratan. Sehingga dibutuhkan suatu kerjasama dan koordinasi untuk menghindari arogansi masing-masing sektor dalam mengimplementasikan program pembangunannya. Selain itu stakeholder terkait seperti pihak pemerintah, swasta, akademisi, Lembaga Swadaya Masyarakat, dan masyarakat pun perlu diakomodir bersama-sama dalam penentuan kebijakan yang berhubungan dengan pengelolaan perairan pesisir, laut dan pulau-pulau kecil untuk penyamaan persepsi.

Prinsip ke-3, adanya Keterpaduan antara level pemerintahan, baik pusat maupun daerah, terdapat komunikasi 2 (dua) arah dan kerjasama yang harmonis antar level pemerintahan, agar tidak terjadi kesalahan dan ketidakakuratan dalam melakukan perencanaan dan pengimplementasian program pembangunan.
Menerapkan suatu pengelolaan terpadu berbasis ekosistem akan memerlukan suatu dasar yang kuat dari pentabiran lautan yang efektif di tingkat nasional dan daerah (Propinsi, Kabupaten/Kota); perbaikan dalam penelitian dan pemantauan yang memberikan informasi yang benar sebagai dasar pengambilan keputusan; serta suatu etika atau stewardship yang diperkuat antara semua penduduk yang dapat dicapai melalui pendidikan formal dan informal (Bengen, 2005:95).

Pengelolaan wilayah di pesisir dan laut secara terpadu mutlak harus memperhatikan keterkaitan dan kapasitas fungsional ekosistem pesisir dan laut dan juga pengaruh dari lahan atas, di samping pentingnya sebuah keterpaduan sektor dan berbagai pemangku kepentingan ataupun stakeholders. Pemberdayaan masyarakat pesisir memang menjadi semakin relevan seiring dengan terjadinya transformasi sosial yang tidak hanya bersifat lokal, tapi juga bersifat regional dan bersifat global. Dengan demikian, pemberdayaan masyarakat sebenarnya merupakan bagian integral dari upaya suatu bangsa untuk menghadapi tantangan yang bersifat global (Bengen, 2005:110).

Sejalan dengan adanya semangat desentralisasi yang berintikan demokrasi, perumusan kebijakan wilayah pesisir dan laut secara terpadu dan partisipatif merupakan tuntutan yang tidak bisa dihindarkan. Kebijakan pesisir dan laut yang berskala nasional, dalam proses perumusannya harus sedemikian rupa sehingga kepentingan-kepentingan pihak yang terkait dapat terakomodasi secara adil dan proporsional, yaitu baik peranan dari bawah maupun dari atas dengan dijalin melalui pola kepentingan bersama (co-management) (Bengen, 2005:110).

Prinsip pengelolaan yang terpadu ini dilakukan berdasarkan pada pertimbangan bahwa pemanfaatan sumberdaya pesisir pada saat ini tidak boleh dengan hanya mengorbankan kebutuhan sumberdaya pesisir bagi generasi mendatang. Prinsip ini lebih efektif dilaksanakan pengelolaannya bersifat demokratis, transparan dan didesentralisasikan ke level yang pemerintahan rendah yang melibatkan masyarakat pesisir setempat (Arifin Rudyanto, 2004:5).

\section{Pengelolaan Wilayah Kelautan Berkelanjutan dalam Perspektif Otonomi Daerah}

Dalam penjelasan umum UUTR angka 1 (satu) disebutkan bahwa ruang wilayah Negara Kesatuan Republik Indonesia (NKRI), baik sebagai kesatuan wadah yang meliputi ruang darat, ruang laut, ruang angkasa yang termasuk ruang dalam bumi, maupun sumber daya adalah merupakan karunia Tuhan Yang 
Maha Esa pada bangsa Indonesia yang perlu disyukuri dan dilindungi serta dikelola secara berkelanjutan untuk sebesar-besarnya kemakmuran rakyat sesuai dengan amanat yang terkandung dalam Pasal 33 ayat (3) UUD 1945, serta makna yang terkandung dalam falsafah dan dasar negara Pancasila.

Pembangunan berkelanjutan adalah merupakan suatu pembangunan yang dapat memenuhi kebutuhan generasi sekarang dan tanpa harus mengorbankan generasi yang akan datang untuk dapat memenuhi kebutuhannya. Lebih jauh, dapat dikatakan bahwa pada tingkat yang sangat minimum, pembangunan berkelanjutan tidak boleh membahayakan sistem alam yang mendukung semua kehidupan di muka bumi ini. Menurut Komisi Dunia untuk lingkungan hidup dan pembangunan (yang selanjutnya disebut WCED) pembangunan berkelanjutan merupakan suatu bentuk pembangunan yang memperhatikan kepentingan generasi kini dan generasi yang akan datang (Alvi Syahri, 2003:77). WCED yang diketuai oleh Harlem Brundtland, dalam laporan tersebut didefinisikan istilah pembangunan berkelanjutan (sustainable development), dan yang menyebutkan bahwa pembangunan berkelanjutan adalah merupakan pembangunan yang diorientasikan untuk memenuhi kebutuhan generasi sekarang tanpa mengorbankan kemampuan generasi muda yang akan datang untuk memenuhi kebutuhan mereka sendiri maka ada empat (4) prinsip dalam mencapai pembangunan yang harus dipenuhi yang meliputi: pemenuhan kebutuhan hidup manusia (fulfillment of human needs); yakni dengan memelihara integritas-integritas ekologi (maintenance of ecological integrity); keadilan sosial (social equity); kesempatan dalam menentukan nasib sendiri (self determination) (Sudharto P. Hadi, 2005:43-44).

Menurut pendapat Juniarso Ridwan, adapun upaya terhadap pelaksanaan perencanaan penataan ruang yang bijaksana adalah kunci dalam pelaksanaan tata ruang agar tidak merusak lingkungan hidup, dalam konteks penguasaan negara atas dasar sumber daya alam, yang melekat di dalam kewajiban negara untuk melindungi, melestarikan, memulihkan lingkungan hidup secara utuh. Artinya, aktifitas pembangunan yang dihasilkan dari perencanaan tata ruang pada umumnya bernuansa pemanfaatan terhadap sumber daya alam tanpa dengan merusak lingkungan (Juniarso Ridwan dan Achmad Sodik, 2008:39).

Dalam pembangunan berkelanjutan terkandung dua gagasan penting yaitu pertama adalah gagasan kebutuhan yaitu kebutuhan esensial yang memberi keberlanjutkan kehidupan manusia. Kedua gagasan keterbatasan yang bersumber pada kondisi teknologi dan organisasi sosial terhadap kemampuan lingkungan untuk memenuhi kebutuhan kini dan hari depan. yang selanjutnya Djajadiningrat menyatakan bahwa setiap elemen pembangunan berkelanjutan dapat diuraikan menjadi empat hal yaitu, pemerataan dan keadilan sosial, keanekaragaman, integratif, perspektif jangka panjang. Sementara itu Dahuri menulis indikator pembangunan berkelanjutan di dalam pengelolaan sumber daya keanekaragaman hayati di laut, yang minimal harus meliputi 4 dimensi yaitu, ekonomi, sosial, ekologi, pengaturan (governance).

\section{PENUTUP \\ Kesimpulan}

Perencanaan serta pengelolaan secara terpadu wilayah laut tidak dapat dilepaskan dari wilayah pesisir serta konsep ekosistem yang terkait dengan wilayah daratan, lautan serta pesisir. Keterpaduan sendiri mengandung 3 (tiga) dimensi yaitu sektoral, bidang ilmu, dan keterkaitan ekologis. Sejalan dengan semangat desentralisasi yang berintikan demokrasi, dengan adanya perumusan kebijakan perencanaan pengelolaan wilayah pesisir dan laut secara terpadu dan partisipatif merupakan tuntutan yang tak bisa dihindarkan serta dalam proses perumusannya harus sedemikian rupa sehingga kepentingan-kepentingan pihak yang terkait dapat terakomodasi secara adil dan proporsional. Baik peranan dari bawah maupun dari atas dengan dijalin melalui pola kepentingan bersama, dapat dilakukan berdasarkan pertimbangan bahwa pemanfaatan sumberdaya kelautan pesisir saat ini tidak boleh mengorbankan kebutuhan bagi generasi yang akan datang, hal ini bisa lebih efektif dilaksanakan bila pengelolaannya bersifat demokratis, transparan dan berkelanjutan.

\section{Rekomendasi}

Dalam pembangunan berkelanjutan terkandung dua gagasan penting yaitu pertama adalah gagasan kebutuhan yaitu kebutuhan esensial yang memberi keberlanjutkan kehidupan manusia. Kedua gagasan keterbatasan yang bersumber pada kondisi teknologi dan organisasi sosial terhadap kemampuan lingkungan untuk memenuhi kebutuhan kini dan hari depan.

\section{DAFTAR PUSTAKA \\ Buku:}

Bengen, 2005, Buku Narasi menuju Harmonisasi Sistem Hukum sebagai Pilar Pengelolaan Wilayah Pesisir Indonesia, Jakarta: Bappenas.

Dahuri, Rokhmin, et. al., 2001, Pengelolaan Sumberdaya Wilayah Pesisir dan Lautan Secara 
Terpadu, Jakarta: Pradnya Paramita.

Dahuri, Rokhmin, 2003, Keanekaragaman Hayati Laut, Aset Pembangunan Berkelanjutan Indonesia. Jakarta: Gramedia Pustaka Utama.

Hadi, Sudharto P., 2005, Dimensi Lingkungan Perencanaan Pembangunan, Yogyakarta: Gadjah Mada University Press.

Kusumastanto, Tridoyo, 2002, Indonesia Ocean Outlook 2004 "Laut Masa Depan Bangsa", PKSPL-IPB.

Parlindungan, A.P., 1998, Komentar atas UndangUndang Pokok Agraria dilengkapi PP 40 dan 41 Tahun 1996, Bandung: Mandar Maju.

Prihatin, Eko Sabar, 2006, Otonomi Daerah dan Pengelolaan Sumber Daya Alam, Laporan hasil penelitian Fakultas Hukum Universitas Dipenorogo.

Ridwan, Juniarso dan Achmad Sodik, 2008, Hukum Tata Ruang dalam Konsep Kebijakan Otonomi Daerah, Cetakan I, Bandung: Nuansa.

Rudyanto, Arifin, Kerangka Kerjasama dalam Pengelolaan Sumberdaya Pesisir dan Laut, Makalah Disampaikan pada Sosialisasi Nasional Program MFCDP, 22 September 2004.
Silalahi M. Daud, 2001, Hukum Lingkungan dalam Sistem Penegakan Hukum Lingkungan Indonesia, Bandung: Alumni.

Syahri, Alvi, 2003, Pengaturan Hukum dan Kebijakan Pembangunan Perumahan dan Permukiman Berkelanjutan, Cetakan I, Medan: Pustaka Bangsa Press.

\section{Peraturan Perundang-undangan:}

Undang-Undang Dasar Negara Republik Indonesia Tahun 1945.

Undang-Undang Nomor 5 Tahun 1960 tentang Peraturan Dasar Pokok-Pokok Agraria (LNRI1960-104, TLN-2043).

Undang-Undang Nomor 32 Tahun 2004 tentang Pemerintahan Daerah (LNRI-2004-125, TLN4437).

Undang-Undang Nomor 26 Tahun 2007 tentang Penataan Ruang (LNRI-2007-68, TLN-4725).

Keputusan Menteri Pemukiman dan Prasarana Wilayah Nomor 327/KPTS/2002 tentang Penetapan Enam Pedoman Bidang Penataan Ruang. 